\title{
Pelaksanaan Pembelajaran Daring Berbantuan Video Tutorial pada Masa Pandemi Covid-19
}

\author{
I Gede Arke ${ }^{1 *}$, Made Agus Wijaya ${ }^{2}$, Kadek Yogi Parta Lesmana ${ }^{3}$ \\ 1,2,3 Prodi Pendidikan Olahraga, Universitas Pendidikan Ganesha, Singaraja, Indonesia
}

\section{ARTICLE INFO \\ Article history: \\ Received May 24, 2021 \\ Revised May 26, 2021 \\ Accepted September 17, 2021 \\ Available online October 25, 2021}

Kata Kunci:

Pembelajaran Daring; Video

Tutorial, PJOK

Keywords:

Online Learning; Video Tutorials, PJOK

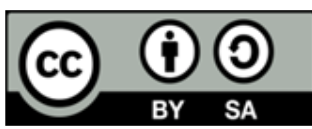

This is an open access article under the CC BY-SA license.

Copyright $(2021$ by Author. Published by Universitas Pendidikan Ganesha.

\begin{abstract}
A B S T R A K
Pandemi covid 19 membawa dampak terhadap pembelajaran pendidikan jasmani dan kesehatan. Salah stuanya kesulitan guru dalam menyampaikan materi pembelajaran tanpa media yang memadai. Tujuan penelitian ini yaitu untuk mengetahui keterlaksanaan pembelajaran daring berbantuan video tutorial. Jenis penelitian ini yaitu deskriptif kuantitatif-kualitatif dengan jenis survei. Jumlah sampel dalam penelitian ini yaitu 70 orang peserta. Metode pengumpulan data yang digunakan adalah kuesioner berbantuan goggle form. Setelah data terkumpul, kemudian di analisis menggunakan tehnik analisis data yang digunakan adalah analisis deskriptif kuantitatif-kualitatif. Hasil penelitian menunjukkan bahwa keterlaksanaan pembelajaran daring berbantuan video tutorial yaitu sebanyak 31 orang $(44,3 \%)$ siswa masuk dalam kategori sangat baik, 35 orang (50\%) siswa masuk dalam kategori baik, 4 orang $(5,7 \%)$ siswa masuk dalam kategori cukup baik, dan tidak terdapat peserta siswa kategori kurang dan tidak baik. Jadi dapat disimpulan penelitian ini adalah pelaksanaan pembelajaran daring berbantuan video tutorial menurut pendapat siswa kelas XI SMA Negeri 3 Singaraja termasuk pada kategori baik, dengan rata-rata skor 76,7 , hal ini diperkuat dengan hasil wawancara peserta didik merasa termotivasi dan mudah dalam memahami materi pembelajaran dengan video tutorial. Disarankan kepada guru PJOK untuk mengimplementasikan pembelajaran berbantuan video tutorial.
\end{abstract}

\section{A B S T RAK}

The COVID-19 pandemic has impacted learning, physical education and health. One of the problems is the teacher's difficulty in delivering learning materials without adequate media. This study aimed to determine the implementation of online learning assisted by video tutorials. This type of research is descriptive quantitative-qualitative with the type of survey. The number of samples in this study was 70 participants. The data collection method used is a questionnaire assisted by a goggle form. After the data is collected, it is then analyzed using the data analysis technique used is quantitative-qualitative descriptive analysis. The results showed that the implementation of online learning assisted by video tutorials was 31 students (44.3\%) in the outstanding category, 35 (50\%) students in the excellent category, 4 (5.7\%) students in the category is quite good, and there are no student participants in the less and not good categories. So it can be concluded that this research is the implementation of online learning assisted by video tutorials in the opinion of class XI students of SMA Negeri 3 Singaraja, including in the excellent category, with an average score of 76.7. It is reinforced by the results of interviews that students feel motivated and easy to understand the material. Learning with video tutorials. It is recommended for PJOK teachers to implement video tutorial assisted learning.

\section{PENDAHULUAN}

Pandemi Covid-19 telah mewabah di seluruh dunia tidak terkecuali Indonesia. Pandemi Covid-19 membawa dampak terhadap perubahan di bidang ekonomi, sosial, politik hingga pendidikan (Ismawati \& Prasetyo, 2021; Sadikin, A., \& Hamidah, 2020). Untuk mencegah penyebaran virus pemerintah mengeluarkan beberapa kebijakan yaitu isolasi, bekerja dari rumah hingga social distancing (Mandailina, Syaharuddin, Pramita, Ibrahim, \& Haifaturrahmah, 2021; Syah, 2020). Dampak terhadap bidang 
pendidikan yaitu perubahan sistem pembelajaran secara derastis dari pembelajaran tatap muka menjadi pembelajaran di rumah atau pembelajaran daring (Al-Bari \& Saputri, 2020; Pujilestari, 2020; Suhendro, 2020). Pembelajaran daring merupakan sistem pembelajaran yang dilakukan dengan menggunakan digital platform atau menggunakan model interaktif berbasis Internet dan Learning Manajemen System (LMS) dengan tidak bertatap muka langsung antara guru maupun siswa. (Asmuni, 2020; Sofyana \& Rozaq, 2019). Kegiatan pembelajaran daring dilakukan dengan di sesuaikan kemampuan masing-masing sekolah. Pembelajaran daring dapat dilakukan dengan menggunakan teknologi digital seperti, gogoole classroom, zoom, video convrence, dan berbagai bentuk layanan belajar lainya (Ayudia, Febrialismanto, \& Solfiah, 2020; Harahap, Dimyati, \& Purwanta, 2021). Pembelajaran daring diharapkan mampu memberikan kemudahan bagi siswa dan guru untuk melaksanakan proses pembelajaran tanpa takut terinfeksi virus covid -19. Guru memegang peranan penting dalam pelaksanaan pembelajaran daring yaitu guru guna tercapaianya tujuan pembelajaran guru harus dapat menciptakan suasana pembelajaran yang efektif dan efisien (Pujiasih, 2020; Saifulloh \& Darwis, 2020).

Namun berdasarkan hasil observasi dan wawancara pembelajaran daring berdampak besar pada proses pembelajaran peserta didik di sekolah. Peserta didik merasa di paksa belajar jarak jauh tanpa sarana dan prasarana yang memadai di rumah. Fasilitas, ini sangat penting untuk kelancaran peroses belajar mengajar. Pembelajaran daring dirumah seharusnya tersedia fasilitas seperti laptop, komputer, ataupun handphone yang akan memudahkan peserta didik untuk mengikuti suatu proses pembelajaran daring. Peserta didik juga belum memiliki budaya belajar secara daring karena selama ini proses pembelajaran di lakukan secara tatap muka (Abidah, Hidaayatullah, Simamora, Fehabutar, \& Mutakinati, 2020; Latip, 2020). Pembelajaran daring di masa pandemi covid-19 ini juga berdampak pada guru karena tidak semua guru mahir menggunakan teknologi internet atau media sosial sebagai sarana pembelajaran PJOK. Selain itu pembelajran daring juga terkendala oleh jaringan internet yang tidak stabil atau bahkan tidak ada (Iftitah \& Anawaty, 2020; N. Khikmah, Lovia, Zahro, \& Azizah, 2021; Sadikin, A., \& Hamidah, 2020). Pelaksanaan pembelajaran daring dapat berjalan dengan baik jika jaringan internet bagus dan media yang digunakan menarik, tetapi apabila jaringan internet itu buruk maka pembelajaran akan terhambat di karenakan siswa sulit untuk mengakses materi yang di sampaikan secara daring oleh guru.

Pendidikan jasmani, olahraga, dan kesehatan (PJOK) merupakan bagian dari pendidikan nasional yang harus melibatkan unsur-unsur penting berupa fikiran dan tubuh. Dimana semua aspek tersebut sangat berkaitan dalam kehidupan sehari-hari untuk menjadikan masing-masing individu agar menjadi baik (Junaedi, 2015). PJOK merupakan suatu kegiatan yang secara sadar disusun dengan sistemik dan bertujuan untuk mengembangkan fitness, fungsi organ tubuh, kontrol neuro-muscular, kekuatan intelektual, pengendalian emosi (Indrawathi, Dewi, \& Widiantari, 2021). Pertumbuhan perkembangan anak melalui aktivitas jasmani yang di pilih dengan tujuan yang jelas. PJOK merupakan suatu proses pembelajaran melalui aktivitas jasmani yang didesain untuk meningkatkan kebugaran jasmani, pengetahuan dan perilaku hidup sehat dan kecerdasan emosi (Lesmana, 2018; Mashuri, 2017). PJOK merupakan bagian integral dari pendidikan secara keseluruhan,yang bertujuan untuk mengembangkan aspek kebugaran jasmani, keterampilan gerak, keterampilan berfikir kritis, keterampilan sosial, penalaran, stabilitas emosional, tindakan moral, aspek pola hidup sehat, dan pengenalan lingkungan bersih melalui jasmani.

Dari pengertian tiga ahli di atas PJOK dalam penelitian ini merupakan mata pelajaran yang mencakup seluruh aspek pendidikan dengan rancangan yang sistematis serta mencapai tujuan pendidikan nasional. Aspek yang terkandung dalam mata pelajaran PJOK diantaranya, aspek kebugaran jasmani, pola hidup sehat, keterampilan gerak, keterampilan sosial, berpikir kritis, serta stabilitas emosional (A. Khikmah, 2019). PJOK tidak hanya menuntut siswa untuk berpikir secara individu dalam menyelesaikan masalah, namun siswa juga dituntut untuk aktif di lapangan serta mampu untuk bekerjasama dengan kelompok, Karena pembelajaran PJOK yang lebih dominan aktivitas fisik tanpa mengabaikan aspek pengetahuan dan sikap peserta didik maka perlu adanya media yang dapat menyajikan pemahaman tentang aktivitas fisik.

Media pembelajaran merupakan alat bantu yang digunakan untuk meransang pikiran, perasaan, perhatian, dan kemampuan dalam suatu proses pembelajaran guna untuk mencapai suatu tujuan pembelajaran secara maksimal. Media pembelajaran merupakan salah satu komponen pembelajaran yang mempunyai peranan penting dalam kegiatan belajar mengajar (Nurdyansah, 2019). Ketepatan penggunaan media pembelajaran dapat memepengaruhi kualitas proses serta hasil yang dicapai. Media pembelajaran merupakan "perangkat lunak" (Software) yang berupa pesan atau sajian informasi tentang pendidikan yang di sajikan dengan menggunaan alat bantu yang berupa (Hardware) agar pesan atau informasi tersebut dapat sampai kepada siswa (Ahdan, Putri, \& Sucipto, 2020; Muhson, 2010; R. A. Pratiwi, Purnomo, \& Mimi Haetami, 2018). Media yang bersifat interaktif juga menyediakan berbagai peluang kepada para pengajar untuk mengaplikasikan metode pembelajaran dan memberikan pilihan 
pada siswa untuk menentukan tehnik belajar yang sesuai dengan ke inginan mereka yaitu pengalaman dan suasana yang menarik. Salah satu media yang dapat digunakan dalam proses pembelajaran pada masa pandemi ini adalah video pembelajaran. Media dalam bentuk video dapat melatih pendengaran dan penglihatan anak karena video pembelajaran audio visual merupakan perpaduan antara materi visual dan auditif yang menjadikan peserta didik mampu menerima pesan belajar melalui visualisasi dan melalui pendengaran (Nurdin et al., 2019). Video tutorial merupakan suatu alternatif yang dapat menunjang suatu proses pembelajaran khususnya di pembelajaran PJOK.

Video tutorial merupakan rangkaian gambar hidup yang ditayangkan oleh seorang pengajar kepada peserta didik yang berisi pesan-pesan pembelajaran guna memberikan pemahaman terhadap suatu materi sebagai bimbingan atau bahan pembelajaran kepada sekelompok peserta didik (Erni \& Farihah, 2021). Video tutorial memiliki kelebihan yaitu tampilannya menarik perhatian, dengan perekaman video beberapa penonton memperoleh informasi dari ahlinya, demonstrasi biasanya sulit disiapkan dan direkam, pada waktu belajar dosen dapat memusatkan perhatian mahasiswa pada penyajiannya, efisiensi waktu dan rekaman yang sudah dibuat dapat diputar ulang, dapat mengamati objek, lebih dekat dengan objek yang sedang bergerak, keras atau lemahnya suara bisa disesuaikan, gambar proyeksi bisa dibekukan (pause) untuk mengamati gambar dengan seksama. Kemudian menurut kamus besar Bahasa Indonesia (2012 : 907), Tutorial adalah (1) Pembimbingan kelas oleh seorang pengajar (tutor) untuk seorang atau sekelompok kecil mahasiswa, (2) pengajaran tambahan melalui tutor. Sehingga dapat dikatakan bahwa tutorial adalah sebuah pengajaran yang di lakukan oleh seorang ahli kepada sekelompok orang. Dimasa pandemi ini media pembelajaran berupa video tutorial sangat penting untuk menunjang suatu proses pembelajaran yang mampu memberikan visualisasi yang baik terhadap mata pelajaran PJOK. Hal ini sejalan dengan hasil penelitian oleh 1) (Mahlianurrahman \& Syamsu, 2019) yang menunjukkan hasil bahwa video tutorial produk media pada materi gaya yang layak untuk pembelajaran IPA terhadap keterampilan proses siswa, 2) penelitian oleh (Batubara \& Batubara, 2020) menunjukkan hasil bahwa penggunaan video tutorial di masa pandemi virus corona dapat melengkapi sarana pembelajaran daring. Penelitian oleh (Restu Emidal Putri \& Iswari, 2019) menunjukkan bahwa video tutorial efektif untuk meningkatkan keterampilan anak. Keberhasilan dari suatu model ataupun media pembelajaran tergantung dari karakteristik peserta didiknya. Dengan adanya media pembelajaran berupa video tutorial diharapkan dapat memberikan hasil yang maksimal.

Penelitian mengenai survei pelaksanaan pembelajaran daring berbantuan pada masa pandemi covid-19 telah diteliti di berbagai tempat dengan hasil yang bervariasi. Adapun hal yang membedakan antara penelitian ini dengan penelitian sebelumnya yakni penelitian ini menggunakan video tutorial sebagai media pembelajarannya. Tujuan dari penelitian ini untuk mengetahui keterlaksanaan pembelajaran daring berbantuan video tutorial.

\section{METODE}

Penelitian ini merupakan jenis penelitian deskritif kuantitatif-kualitatif dengan jenis penelitian survei. Populasi dalam penelitian ini adalah seluruh siswa kelas XI SMA Negeri 3 Singaraja dan dipilih kelas secara random. Adapun jumlah peserta didik kelas XI SMA Negeri 3 Singaraja yaitu 345 peserta didik. Sampel dalam penelitian ini $20 \%$ x $345=70$ yaitu 70 orang peserta didik kelas XI SMA Negeri 3 Singaraja. Metode pengumpulan data dalam penelitian ini terdiri dari 2 bagian yaitu menggunakan instrument penilaian berupa kuesioner dan wawancara. Instrumen yang digunakan dalam penelitian ini adalah berupa kuesioner tertutup yang berorientasi pada keterampilan mengajar berbasis daring. Wawancara digunakan sebagai teknik pengumpulan data bertjuan untuk menemukan permasalahan yang akan diteliti dan informasi secara mendalam (Sugiyono, 2017). Kuesioner digunakan untuk memperoleh sebuah informasi yang berkaitan dengan sikap, opini, harapan dan keinginan dalam bentuk pertanyaan kepada responden (Neyfa \& Tamara, 2016). Proses wawancara dilakukan guna memperoleh data pada proses pembelajaran yang bersifat terbuka pada kegiatan yang dilaksanakan dan memperoleh kebutuhan yang diperlukan pada pelaksanaan pembelajaran daring. Metode analisis data yang digunakan dalam penelitian ini yaitu menggunakan metode analisis statistik deskriptif kuantitatif. Kemudian data yang diperoleh berupa skor hasil pengisian kusioner/angket oleh guru dianalisis mengggunakan teknik analisis statistik deskriptif berupa penentuan mean dan persentase data.

\section{HASIL DAN PEMBAHASAN}

\section{Hasil}

Dalam penelitian Survei Pelaksanaan Pembelajaran Daring Berbantun Video Tutorial dilihat dari pelaksanaan pembelajaran daring. Teknik perhitungan data yang di kategorikan dengan interval kategori, 
dalam penelitian ini data dikategorikan menjadi 5 yaitu : sangat baik, baik, cukup baik, kurang baik, dan sangat kurang baik. Pengkategorikan tersebut dibuat berdasarkan hasil skor diperoleh yang merupakan hasil perhitungan deskriptif yang telah dilakukan sebelumnya.

Berikut hasil analisis deskriptif pelaksanaan pembelajaran daring berbantun video tutorial menurut pendapat siswa kelas XI SMA Negeri 3 Singaraja dilihat dari pelaksanaan pembelajaran daring, yang disajikan pada Tabel 1.

Tabel 1. Analisis Data Pelaksanaan Pembelajaran daring Berbantuan Video Tutorial

\begin{tabular}{llccc}
\hline No & Indikator & Nomor Butir & $\begin{array}{c}\text { Skor Minimum } \\
\text { Peserta Didik }\end{array}$ & $\begin{array}{c}\text { Skor Maksimum Peserta } \\
\text { Didik }\end{array}$ \\
\hline 1 & Salam dan Doa & 1,2 & 6 & $\mathbf{8}$ \\
2 & Tujuan & 3 & 1 & $\mathbf{4}$ \\
3 & Membelajaran & 4,5 & 2 & $\mathbf{8}$ \\
4 & Mativasi siswa & $6,7,8,9$ & 10 & $\mathbf{1 6}$ \\
5 & pembelajaran & $10,11,12,13,14$ & 11 & $\mathbf{2 4}$ \\
6 & Praktek & 15 & 8 & $\mathbf{1 6}$ \\
7 & Penugasan & $16,17,1819$ & 2 & $\mathbf{8}$ \\
8 & Refleksi & 20,221 & 1 & $\mathbf{4}$ \\
\hline 9 & Salam dan Doa & 22 & $\mathbf{3}$ & $\mathbf{4}$ \\
\hline
\end{tabular}

Berdasarkan Tabel 1, diketahui bahwa pelaksanaan pembelajaran daring berbantuan video utorial menurut pendapat siswa kelas XI SMA Negeri 3 Singaraja, diamati dari beberapa inndkator yaitu, salam dan doa, tujuan pembelajaran, motivasi siswa, materi pembelajaran, pemahaman, praktek, penugasan, refleksi, dan salam doa penutup.

Diketahui bahwa pelaksanaan pembelajaran daring berbantuan video utorial menurut pendapat siswa kelas XI SMA Negeri 3 Singaraja, diamati dari beberapa inndkator yaitu, salam dan doa, tujuan pembelajaran, motivasi siswa, materi pembelajaran, pemahaman, praktek, penugasan, refleksi, dan salam doa penutup.

Tabel 2. Prsentase Pelaksanaan Pembelajaran Daring Berbantuan Video Tutorial Menurut Pendapat Siswa Kelas XI SMA N 3 Singaraja

\begin{tabular}{cclc}
\hline No & Aspek & \multicolumn{1}{c}{ Indikator } & Persentase Skor \\
\hline 1 & & Salam dan Doa & $\mathbf{9 , 6 \%}$ \\
2 & Pendahuluan & Tujuan Pembelajaran & $\mathbf{4 , 6 \%}$ \\
3 & & Motivasi siswa & $\mathbf{8 , 6 \%}$ \\
4 & & Materi & $\mathbf{1 7 , 6 \%}$ \\
5 & & Pemahaman & $\mathbf{2 5 , 2 \%}$ \\
6 & Inti & Praktek & $\mathbf{1 7 \%}$ \\
7 & & Penugasan & $\mathbf{8 , 3 \%}$ \\
8 & & Refleeksi & $\mathbf{4 , 1 \%}$ \\
9 & & Salam dan doa & $\mathbf{4 , 7 \%}$ \\
\hline \multicolumn{4}{c}{} \\
\hline
\end{tabular}

Prsentase pelaksanaan pembelajaran daring berbantuan video tutorial dketahui pada indkator salam dan doa pembuka 9,6\%, Indikator tujuan pembelajaran 4,6\%, motivasi siswa 8,6, Indikator Materi Pemelajaran 17,6\%, Indikator pemahaman 25,2\%, indikator Praktek 17\%, indikator penugasan 8,3\%, Indikator refleksi 4,1\% dan pada indikator salam dan doa penutup 4,7\%. Maka berdasarkan hasil tersebut indikator tertinggi adalah pemahaman dengan jumlah prsentase sebesar $25,2 \%$.

Data dalam penelitian Pelaksanaan pembelajaran daring berbantuan video tutorial menurut pendapat siswa kelas XI SMA Negeri 3 Singaraja, dianalisis menggunakan teknik statistik deskriptif. Dalam penelitian ini, data dikategorikan menjadi 5 yaitu: sangat baik, baik, cukup baik, kurang dan tidak baik. Pengkategorian tersebut dibuat berdasarkan mean ideal dan standar deviasi ideal yang merupakan hasil perhitungan deskriptif yang telah dilakukan sebelumnya.

Pelaksanaan pembelajaran daring berbantuan video tutorial menurut pendapat siswa kelas XI SMA Negeri 3 Singaraja, telah diukur menggunakan angket yang terdiri dari 23 butir pernyataan. Dari 
hasil analisis data yang telah dilakukan, terhadap pelaksanaan pembelajaran, maka diperoleh rerata sebesar 76,7, median sebesar 76,5, modus sebesar 72, dan standar deviasi ideal sebesar 8,09. Distribusi frekuensi pengkategorian dapat dilihat pada tabel 3.

Tabel 3. Analisis Pelaksanaan Pembelajaran Daring Berbantuan Video Tutorial menurut Pendapat Siswa Kelas XI SMA Negeri 3 Singaraja

\begin{tabular}{cccc}
\hline Interval & Frekuensi (Orang) & Presentase (\%) & Kategori \\
\hline $79-92$ & 31 & $44,3 \%$ & Sangat Baik \\
$65-78$ & 35 & $50 \%$ & Baik \\
$51-64$ & 4 & $5,7 \%$ & Cukup Baik \\
$37-50$ & 0 & $0,00 \%$ & Kurang \\
$23-36$ & 0 & $0,00 \%$ & Tidak Baik \\
\hline Total & $\mathbf{7 0}$ & $\mathbf{1 0 0 \%}$ & \\
\hline
\end{tabular}

Mengacu tabel 5. Ditemukan bahwasannya sebanyak 31 orang siswa sebesar 44,3\% termasuk pada kategori Sangat baik, 35 orang siswa atau 50\% termasuk pada kategori baik, 4 orang siswa atau $5,7 \%$ masuk pada kategori cukup baik, 0 siswa atau 0,00\% masuk pada kelompok kurang, serta 0 siswa ataupun $0,00 \%$ masuk dalam kategori tidak baik. Bilamana diamati pada frekuensi yang mana terbentuk pada tiap frekuensi maupun total siswa yang timbul di setiap kelompok, sehingga bisa ditemukan pelaksanaan pembelajaran daring berbantuan video tutorial menurut pendapat siswa kelas XI SMA Negeri 3 Singaraja, berada dalam kategori baik.

\section{Pembahasan}

Berdasarkan analisis hasil penelitian ditemukan bahwa pelaksanaan pembelajaran daring berbantuan media pembelajaran berupa video tutorial memperoleh hasil yang baik. Hal ini menunjukan bahwa guru sudah mampu menerapkan karakteristik keterampilan mengadakan variasi berbasis daring dengan baik, yang mana seorang guru harus memiliki keterampilan dasar mengajar yang baik salah satunya dapat mengadakan variasi agar pembelajaran menjadi menarik dan anak fokus sehingga tujuan pembelajaran dapat tercapai. Pembelajaran merupakan kegiatan interaksi antara guru dan peserta didik di kelas (Putria, Maula, \& Uswatun, 2020). Dalam proses pembelajaran melibatkan kegiatan belajar dan mengajar yang dapat menentukan keberhasilan siswa serta untuk mencapai tujuan pendidikan belajar merupakan suatu perubahan perilaku yang terjadi pada individu, yang sebelumnya tidak bisa menjadi bisa atau mahir. Pembelajaran daring yaitu pembelajaran jarak jauh atau juga bisa disebut belajar daring rumah yang dilakukan secara online oleh guru dan siswa untuk melakukan pembelajaran yang seperti di kelas (Yunitasari \& Hanifah, 2020). Hal ini diperkuat dengan hasil wawancara peserta didik yang menyatakan bahwa siswa merasa bosan ketika materi pembelajaran hanya di sampaikan melalui platfoom Wa group saja tetapi dengan video tutorial dapat memotivasi siswa untuk mengikuti pembelajaran daring dan siswa juga tidak merasa bosan ketika materi yang di sampaikan melalui video tutorial karena dapat memudahkan siswa dalam memahami materi, siswa juga dapat memperhatikan contoh dari pembelajaran yang disampaikan pada matapelajaran PJOK yang lebih dominan ke ranah psikomotorik.

Media pembelajaran efektif untuk meningkatkan hasil belajar, kemampuan mahasiswa memberikan respon yang positif terhadap penerapan model pembelajaran langsung berbantuan VCD (Spyanawati \& Lesmana, 2016). Video tutorial dapat memotivasi siswa untuk mengikuti pembelajaran daring dan siswa juga tidak merasa bosan ketika materi yang di sampaikan melalui video tutorial karena dapat memudahkan siswa dalam memahami materi, siswa juga dapat memperhatikan contoh dari pembelajaran yang disampaikan pada matapelajaran PJOK yang lebih dominan ke ranah psikomotorik. Video tutorial juga dapat membantu, karena bisa dijadikan contoh sebagai bahan praktek untuk pembelajaran, terutama pada materi yang memang tidak bisa hanya dengan membaca lewat buku, kualitas video tutorial yang digunakan juga sangat jelas dan dapat membantu, dari video tutorial siswa juga dapat melihat cara ataupun tutorial jadi lebih mudah untuk mengikuti gerakan yang ada pada media video tutorial. Video tutorial yang digunakan dalam proses pembelajaran PJOK ini memuat tentang rangkaian gerakan tehnik-tehnik dasar dalam satu bidang olahraga yang akan dipelajari yang bertujuan agar siswa dapat memahami dan dapat mempraktekan secara maksimal karena dalam video tutorial tersebut memberikan gambaran yang jelas tentang materi yang akan dipelajari sehingga tujuan pembelajaran dapat tercapai walau dalam kondisi pandemi yang mengharuskan siswa belajar secara daring.

Penggunaan media sebagai suplemen dalam pembelajaran juga turut meningkatkan movitasi belajar (Hasanah, Raodatun, I Putu Panca Adi, 2021; Suwiwa \& Astra, 1981). Motivasi belajar meningkat 
karena media video yang disajikan memiliki kejelasan pesan, berdiri sendiri, mudah digunakan oleh peserta didik, isi yang disajikan dalam media sangat representative, media dapat digunakan secara individual dan vusualisasi media video juga dilangkapi teks, animasi, suara yang jelas. Beberapa penelitian sebelumnya yang berkaitan dengan pemanfaatan video tutorial oleh guru selama proses pembelajaran daring menyebutkan bahwa media pembelajaran video tutorial sistem pengapian ini sangat layak diterapkan untuk peserta didik (Utomo \& Ratnawati, 2018). Penelitian lainnya juga menyebutkan bahwa video tutorial cocok digunakan untuk mengilustrasikan suatu peristiwa yang bergerak, prosedur, atapun konsep yang abstrak dan bergerak (Khairi, 2014; Mandalika \& Syahril, 2020; B. Pratiwi \& Hapsari, 2020). Video tutorial juga dapat membantu, karena bisa dijadikan contoh sebagai bahan praktek untuk pembelajaran, terutama pada materi yang memang tidak bisa hanya dengan membaca lewat buku, kualitas video tutorial yang digunakan juga sangat jelas dan dapat membantu, dari video tutorial siswa juga dapat melihat cara ataupun tutorial jadi lebih mudah untuk mengikuti gerakan yang ada pada media video tutorial.

\section{SIMPULAN DAN SARAN}

Berdasar kajian analisa data pelaksanaan pembelajaran daring berbantuan video tutorial dari pembahasan dapat disimpulkan bahwa pelaksanaan pembelajaran daring berbantuan video tutorial berada pada kategori baik, peserta didik juga lebih termotivasi dan mudah dalam memahami materi ketika materi pembelajaran disampaikan melalui video tutorial. Sehingga diharapkan melalui pemanfaatan media toturial memudahakn guru dalam menyamoaikan materi serta menambah ivonasi serta kreatifitas guru dalam proses pembelajaran.

\section{DAFTAR RUJUKAN}

Abidah, A., Hidaayatullah, H. N., Simamora, R. M., Fehabutar, D., \& Mutakinati, L. (2020). The Impact of Covid- 19 to Indonesian Education and Its Relation to the Philosophy of " Merdeka Belajar ." Studies in Philosophy of Science and Education, 1(1), 38 - 49. https://doi.org/10.46627/sipose.v1i1.9.

Ahdan, S., Putri, A. R., \& Sucipto, A. (2020). Aplikasi M-Learning Sebagai Media Pembelajaran Conversation Pada Homey English. Sistemasi, 9(3), 493. https://doi.org/10.32520/stmsi.v9i3.884.

Al-Bari, A., \& Saputri, R. K. (2020). Persepsi Mahasiswa Terhadap Praktikum Daring Mata Kuliah Kimia Analisis. Jurnal Educatio FKIP UNMA, 6(2), 676 - 683. https://doi.org/10.31949/educatio.v6i2.723.

Asmuni, A. (2020). Problematika Pembelajaran Daring di Masa Pandemi Covid-19 dan Solusi Pemecahannya. Jurnal Paedagogy, 7(4), 281-288. https://doi.org/10.33394/jp.v7i4.2941.

Ayudia, R., Febrialismanto, F., \& Solfiah, Y. (2020). Persepsi Orangtua Terhadap Pembelajaran Daring Pada Anak Usia 5-6 Tahun Di Kecamatan Limapuluh Kota Pekanbaru. Jurnal Review Pendidikan Dan Pengajaran, 3(2), 243-248. https://doi.org/10.31004/jrpp.v3i2.1222.

Batubara, H. H., \& Batubara, D. S. (2020). Penggunaan Video Tutorial Untuk Mendukung Pembelajaran Daring Di Masa Pandemi Virus Corona. MUALLIMUNA : JURNAL MADRASAH IBTIDAIYAH, 5(2), 7484. https://doi.org/10.31602/muallimuna.v5i2.2950.

Erni, E., \& Farihah, F. (2021). Pengembangan Media Video Tutorial Pada Mata Kuliah Teknologi Menjahit Dalam Mendukung Pembelajaran Dimasa Pandemi Covid-19. Jurnal Pendidikan Teknologi Dan Kejuruan, 18(1), 121-131. https://doi.org/10.23887/jptk-undiksha.v18i1.30397.

Harahap, S. A., Dimyati, D., \& Purwanta, E. (2021). Problematika Pembelajaran Daring dan Luring Anak Usia Dini bagi Guru dan Orang tua di Masa Pandemi Covid 19. Jurnal Obsesi : Jurnal Pendidikan Anak Usia Dini, 5(2), 1825-1836. https://doi.org/10.31004/obsesi.v5i2.1013.

Hasanah, Raodatun, I Putu Panca Adi, I. G. S. (2021). Survey Pelaksaan Pembelajaran Pjok Secara Daring Pada Masa Pandemi Covid-19 Nurul. Jurnal Kejaora: Jurnal Kesehatan Jasmani Dan Olah Raga, 6(1), 189-196. https://ejournal.unibabwi.ac.id/index.php/kejaora/article/view/1295.

Iftitah, S. L., \& Anawaty, M. F. (2020). Peran Orang Tua Dalam Mendampingi Anak Di Rumah Selama Pandemi Covid-19. JCE Uournal of Childhood Education), 4(2), $71 \quad$ - 81. https://doi.org/10.30736/jce.v4i2.256.

Indrawathi, N. L. P., Dewi, P. C. P., \& Widiantari, N. L. G. (2021). Faktor-faktor yang mempengaruhi hasil belajar pendidikan jasmani, olahraga dan kesehatan pada siswa kelas vii smp negeri 5 kuta $\begin{array}{lllll}\text { selatan. Jurnal Pendidikan } & \text { Kesehatan }\end{array}$ https: //ojs.mahadewa.ac.id/index.php/jpkr/article/view/1026.

Ismawati, D., \& Prasetyo, I. (2021). Efektivitas Pembelajaran Menggunakan Video Zoom Cloud Meeting 
pada Anak Usia Dini Era Pandemi Covid-19. Jurnal Obsesi : Jurnal Pendidikan Anak Usia Dini, 5(1), 665-675. https://doi.org/10.31004/obsesi.v5i1.671.

Junaedi, A. (2015). Survei Tingkat Kemajuan Pendidikan Jasmani, Olahraga, Dan Kesehatan Di Sma, Smk, Dan Ma Negeri Se-Kabupaten Gresik. ,. Journal of Chemical Information and Modeling, 53(9), 168169. Retrieved from https://ejournal.unesa.ac.id/index.php/jurnal-pendidikanjasmani/article/view/14367.

Khairi, A. (2014). Pengembangan Video Tutorial Pada Mata Kuliah Media Pembelajaran Berbasis IT Untuk Mahasiswa PGSD Universitas Bung Hatta. Jurnal CERDAS Proklamator, 2(2), 133-144. https://doi.org/10.37301/jcp.v2i2.7541.

Khikmah, A. (2019). Survei Sarana Dan Prasarana Pendidikan Jasmani Di Madrasah Tsanawiyah (MTS) SeKecamatan Klojen Kota Malang Pada Semester Ganjil Tahun 2017. Sport Science, 1(1), 12-19. http://journal2.um.ac.id/index.php/jospe/article/view/9877.

Khikmah, N., Lovia, L. N., Zahro, F., \& Azizah, F. N. (2021). Pemanfaatan Google Classroom dalam Praktik Microteaching Pembelajaran Fiqih MI bagi Mahasiswa PGMI UIN Walisongo Semarang. Jurnal Studi Guru Dan Pembelajaran, 4(1), 237-246. https://doi.org/10.30605/jsgp.4.1.2021.466.

Latip, A. (2020). Peran Literasi Teknologi Informasi Dan Komunikasi Pada Pembelajaran Jarak Jauh Di Masa Pandemi Covid-19. EduTeach : Jurnal Edukasi Dan Teknologi Pembelajaran, 1(2), 108 - 116. https://ejurnal.umri.ac.id/index.php/eduteach/article/view/1956

Lesmana, H. S. (2018). Peran Motor Educability Di Dalam Meningkatan Keterampilan Olahraga Pada Pembelajaran Penjas. Jurnal Halaman Olahraga Nusantara, 1(1), 115-125. https://doi.org/10.31851/hon.v1i1.1507.

Mahlianurrahman, \& Syamsu, F. D. (2019). Developing Tutorial Video for Enhancing Elementary School Students' Process Skills in Science. Elementary: Jurnal Ilmiah Pendidikan Dasar, 5(1), 1-12. Retrieved from https://e-journal.metrouniv.ac.id/index.php/elementary/article/view/1359.

Mandailina, V., Syaharuddin, Pramita, D., Ibrahim, \& Haifaturrahmah. (2021). Pembelajaran Daring Dalam Meningkatkan Motivasi dan Hasil Belajar Peserta Didik Selama Pandemi Covid-19: Sebuah Meta Analisis. Indonesian Journal of Educational Science (IJES), 03(02), 120-129. https://doi.org/10.31605/ijes.v3i2.955.

Mandalika, M., \& Syahril, S. (2020). Pengembangan Media Pembelajaran Berbasis Video Tutorial untuk Meningkatkan Efektifitas Pembelajaran pada Mata Kuliah Tata Rias Pengantin Indonesia. INVOTEK: Jurnal Inovasi Vokasional Dan Teknologi, 20(1), 85-92. https://doi.org/10.24036/invotek.v20i1.725.

Mashuri, H. (2017). Persepsi Siswa Terhadap Pembelajaran Guru Pendidikan Jasmani Di Sma Muhammadiyah Kediri. Jurnal Pembelajaran Olahraga, 3(1), 1-10. Retrieved from https://ojs.unpkediri.ac.id/index.php/pjk/article/view/681/505.

Muhson, A. (2010). Pengembangan Media Pembelajaran Berbasis Teknologi Informasi.,. Jurnal Pendidikan Akuntansi Indonesia, 8(2). https://doi.org/10.21831/jpai.v8i2.949.

Neyfa, B. C., \& Tamara, D. (2016). Perancangan Aplikasi E-Canteen Berbasis Android Dengan Menggunakan Metode Object Oriented Analysis \& Design ( OOAD). British Medical Journal, 1(6001), 107-109. https://doi.org/10.1136/bmj.1.6001.107.

Nurdin, E., Ma'aruf, A., Amir, Z., Risnawati, R., Noviarni, N., \& Azmi, M. P. (2019). Pemanfaatan video pembelajaran berbasis Geogebra untuk meningkatkan kemampuan pemahaman konsep matematis siswa SMK. Jurnal Riset Pendidikan Matematika, 6(1), 87-98. https://doi.org/10.21831/jrpm.v6i1.18421.

Nurdyansah. (2019). Media Pembelajaran Inovatif. (U. Press., Ed.).

Pratiwi, B., \& Hapsari, K. P. (2020). Analisis Kemampuan Berpikir Tingkat Tinggi Melalui Pemanfaatan YouTube Sebagai Media Pembelajaran Bahasa Indonesia. Jurnal Ilmiah Sekolah Dasar, 4(2), $136-$ 143. https://doi.org/10.23887/jisd.v4i2.24238.

Pratiwi, R. A., Purnomo, E., \& Mimi Haetami. (2018). Pengaruh latihan plyometrik terhadap kecepatan tendangan $\mathrm{T}$ Pencak Silat. Jurnal Pendidikan Dan Pembelajaran Khatulistiwa, 8(11). https://jurnal.untan.ac.id/index.php/jpdpb/article/download/37730/75676584156

Pujiasih, E. (2020). Membangun Generasi Emas Dengan Variasi Pembelajaran Online Di Masa Pandemi Covid-19. Ideguru: Jurnal Karya Ilmiah Guru, 5(1), 42-48. https://doi.org/10.51169/ideguru.v5i1.136.

Pujilestari, Y. (2020). Dampak Positif Pembelajaran Online Dalam Sistem Pendidikan Indonesia Pasca $\begin{array}{llll}\text { Pandemi Covid-19. Adalah, 49-56. } & \end{array}$ http://journal.uinjkt.ac.id/index.php/adalah/article/view/15394.

Putria, H., Maula, L. H., \& Uswatun, D. A. (2020). Analisis Proses Pembelajaran dalam Jaringan (DARING) Masa Pandemi Covid- 19 Pada Guru Sekolah Dasar. Jurnal Basicedu, 4(4), 861-870. 
https://doi.org/10.31004/basicedu.v4i4.460.

Restu Emidal Putri, \& Iswari, M. (2019). Tutorial Video Media of How to Make Dolls from Socks for Students with Intelectual Disability. Jurnal Penelitian Dan Pengembangan Pendidikan Luar Biasa, 6(2), 22-25. https: //doi.org/10.17977/um029v6i22019p22-25.

Sadikin, A., \& Hamidah, A. (2020). Pembelajaran Daring di Tengah Wabah Covid-19. Biodik, 6(2), $109-119$. https: //doi.org/10.22437/bio.v6i2.9759.

Saifulloh, A. M., \& Darwis, M. (2020). Manajemen Pembelajaran dalam Meningkatkan Efektivitas Proses Belajar Mengajar di Masa Pandemi Covid-19. Bidayatuna: Jurnal Pendidikan Guru Mandrasah Ibtidaiyah, 3(2), 285. https://doi.org/10.36835/bidayatuna.v3i2.638.

Sofyana, L., \& Rozaq, A. (2019). Pembelajaran Daring Kombinasi Berbasis Whatsapp Pada Kelas Karyawan Prodi Teknik Informatika. Jurnal Nasional Pendidikan Teknik Informatika, 8(1), 81-86. https://doi.org/10.23887/janapati.v8i1.17204.

Spyanawati, L. ., \& Lesmana, I. K. Y. . (2016). Pengaruh Model Dan Media Pembelajaran Terhadap Hasil Belajar Kemampuan Dasar Senam Lantai Pada Mahasiswa Jurusan Penjaskesrek Undiksha. JPI (Jurnal Pendidikan Indonesia), 5(1), 97. https://doi.org/10.23887/jpi-undiksha.v5i1.8932.

Sugiyono. (2017). Metode Penelitian Kuantitatif, Kualitataif, dan R\&D. Bandung: Alfabeta.

Suhendro, E. (2020). Strategi Pembelajaran Pendidikan Anak Usia Dini di Masa Pandemi Covid-19. Golden Age: Jurnal Ilmiah Tumbuh Kembang Anak Usia Dini, 5(3), 133-140. https://doi.org/10.14421/jga.2020.53-05.

Suwiwa, I. G., \& Astra, I. K. B. (1981). Implementasi Model Pembelajaran Kooperatif Tipe Nht Berbantuan Media Video Untukmeningkatkan Hasil Belajar Renang Gaya Punggung. Journal of Chemical Information and Modeling, 53(9), 1689-1699.

Syah, R. H. (2020). Dampak Covid-19 pada Pendidikan di Indonesia: Sekolah, Keterampilan, dan Proses Pembelajaran. SALAM: Jurnal Sosial Dan Budaya Syar-I, $7(5)$. https://doi.org/10.15408/sjsbs.v7i5.15314.

Utomo, A. Y., \& Ratnawati, D. (2018). Pengembangan Video Tutorial Dalam Pembelajaran Sistem Pengapian Di Smk. Jurnal Taman Vokasi, 6(1), 68. https://doi.org/10.30738/jtvok.v6i1.2839.

Yunitasari, R., \& Hanifah, U. (2020). Pengaruh Pembelajaran Daring terhadap Minat Belajar Siswa pada Masa COVID 19. Edukatif: Jurnal Ilmu Pendidikan, 2(3), 232-243. https://doi.org/10.31004/edukatif.v2i3.142. 